\title{
Living on the Edge: \\ Towards a Monstrous Organization Theory ${ }^{1}$
}

by Torkild Thanem

The final version of this paper is published in Organization (2005), vol. 13, no. 2, pp. 163-193.

\begin{abstract}
Following the recent curiosity for monsters in social and organizational research, this paper questions the power, purity and boundaries of organization by accentuating its risky encounters with heterogeneous, monstrous bodies. In an attempt to problematize organization theory's implicit dissociation of monsters from organization, the understanding and treatment of monsters is traced across a variety of discursive formations in Western history - from Medieval and Renaissance theology and medicine, via Classical life science, freak shows and contemporary performance art, to recent social science and organization theory. Invoking Deleuze and Guattari's (1988) work on creative involution, the paper goes beyond previous social and organizational research in thinking the radicality of monsters, and it concludes with an argument for a monstrous organization theory that (i) encourages organizational researchers to critically reflect about their own monstrosity, (ii) challenges the stigmatization of monstrous embodiment, and (iii) delves into bodies that live on the edge and disrupt organizational boundaries.
\end{abstract}

Keywords: monstrous embodiment, heterogeneity, disrupting organizational boundaries. 
Sometimes a boy, sometimes a girl, and sometimes someone whose androgynous appearance fascinates and disturbs people on the street. A monstrous body who cannot be identified as either/or.

It is only [...] by dint of producing monstrous beings that nature succeeds in producing beings of greater regularity and with more symmetrical structure.

Jean-Baptiste Robinet (1768: 198)

The existence of monsters throws doubt on life's ability to teach us order. [....] A monster is a living being of negative value. [....] the normal type is the zero degree of monstrosity.

Georges Canguilhem (1962: 27; 28; 29)

Five hundred years ago, the sixteenth century storyteller Francois de Belleforest stated that 'the present time is more monstrous than natural' (quoted in Davidson 1991: 41). Asking what would constitute a "natural" degree of monstrosity may seem oxymoronic, but what Belleforest appears to have had in mind was the excess amount of stories, representations and observations of monsters and monstrous phenomena circulating in Europe at the time. As Daston and Park (1996: 198) point out, Belleforest, who wrote the third volume of the Histoire prodigeuses (1575), ${ }^{2}$ 'worried that if the term "monstrous" was applied indiscriminately to everything that was merely rare, it would lose its primary signification as a portent.' In other words, he 
was not so much troubled by the existence of monsters per se, which he apparently held to be at a stable level. Rather, he was anxious to avoid an inflation of terms that would "falsely" exaggerate the level of monstrous phenomena in the world.

Although the interest in monsters since Belleforest has varied, the history of ideas, science and folklore documents a rich diversity of references to monsters, monstrosities and the monstrous, from folktales and mythological accounts of trolls, demigods and mermaids, to theological, medical and biological discussions of monstrous births, hermaphrodites and hybrids. This stands in some contrast to the post-Enlightenment preoccupation with natural laws, pure self identity and homogeneous social order, and in moderns it may invoke an impression that monsters belong to the past. However, modern life and popular culture abounds in monsters. Folktales and urban legend continue to provide an extensive imagery of fantastic figures such as witches, wizards and ghosts with grotesque appearances and superhuman powers. The film industry, the music business and television produce and broadcast images and stories of monsters on a large scale, including frightening mixtures of humans, animals and machines in horror movies, demonic iconography in heavy metal music, and documentaries about sea-monsters and conjoined twins on public television. Furthermore, a literature search for monsters covering the years after 1986 yields more than eight hundred references across the humanities, natural sciences and social sciences, news reports and business magazines. ${ }^{3}$ Although a majority of references is within the natural sciences - from the zoology of Godzilla (see Christiansen 2000) to the biomedicine of monster cells (see Goodman et al. 2002) - headlines in Forbes and Fortune appear, typically associating monsters with the size or seriousness of organizational and financial crisis or fortune, such as in 'Enron's Monster Mess' (Fortune 2002) and 'Monster Cap for Microsoft' (Forbes 1998). 
Moreover, recent humanities research has shown growing interest in the monstrous: monsters in literary fiction, monstrous aspects of migration, female monsters in horror movies, and the construction of womanhood and motherhood as monstrous. ${ }^{4}$ Finally, the past fifteen years or so have seen some social science research on monsters. Though the most famous probably is the quest within Actor-Network Theory for a sociology of monsters (see Law 1991), this even includes discussions in contemporary organization theory (see du Gay 1994; Bloomfield and Vurdubakis 1999; Munro 2001). ${ }^{5}$ Given this vast amount of material, it is evident that the monstrous is the focus of fascination as well as an object of horror, and one could argue that popular and academic preoccupation with the monstrous has itself reached monstrous proportions.

The recent interest in monsters amongst organization theorists is particularly interesting. Whereas the vast majority of organization theory concerns itself with bounded organizational entities and goal-directed processes that seek to inflict order and boundaries by targeting thought and behaviour along certain trajectories (Cooper 1986), monsters are typically associated with that which disrupts boundaries by inhabiting margins and peripheries. Monsters live on the edge. Focusing on the appearance, movement and forces of monstrous bodies as an other of organization, this paper makes some steps towards a monstrous organization theory. On the one hand, attention is drawn to the changing understanding, treatment and organization of monstrous bodies in different power-knowledge regimes (see Foucault 1979, 1980), i.e. what is done to monstrous bodies across certain ruptures in the Western history of ideas, science, culture and institutions. On the other, it asks what a monstrous body is, i.e. what it looks like, where it dwells, and what it can do - to power-knowledge regimes in general and to organization and organization theory in particular. The remainder of the paper consists of six sections. Firstly, it traces the etymological roots 
of the monstrous whilst briefly examining different conceptions and ways of dealing with monsters from Medieval times to the Renaissance. Secondly, it examines the relationship between the monstrous and organization in eighteenth and nineteenth century life science. Thirdly, it examines monstrous bodies in freak shows and performance art that disrupt boundaries of organization. The fourth section investigates previous work on monsters in social science and organization theory. The fifth section examines Deleuze and Guattari's (1988) notion of creative involution in order to open up monstrous embodiment to processes of becoming. Finally, the paper seeks to identify what a monstrous organization theory might entail and what effects living on the edge may have on how organization is thought and lived. Although "living on the edge" connotes to risk behaviour, the focus here is more broadly on the marginality and heterogeneity of monstrous embodiment. That the bulk of organization theory is more concerned with formal organizations and that the study of organizing as a general social process is traditionally addressed in social science research outside organization theory does not necessarily mean that organization theory should confine itself to the study of organizations. Equally, that organization theory to a large extent has tried to normalize its subject matter does not necessarily mean that it should ignore the monstrous forces of embodiment that disrupt processes and entities of organization. As explicit interest in the organizational processes of social life has dropped in other social science, an organization theory that directs attention to the study of monsters in social life may give important insights into the status of formal organizations and to the processes that seek to organize social life outside such entities. 


\section{The disruption of moral, morphological and magnitudinal boundaries}

According to The New Oxford Dictionary of English a monster or monstrosity is a thing, animal or 'imaginary creature that is typically large, ugly, and frightening', 'an inhumanly cruel or wicked person', or 'a person, typically a child, who is rude or badly behaved.' In addition, a monster can be 'a thing or animal that is excessively or dauntingly large' or 'a congenitally malformed or mutant animal or plant.' Similarly, monstrous is that which has 'the ugly or frightening appearance of a monster', but it is also associated with evil, wrongdoing and excessive size. One can therefore argue that monsters, monstrosities and the monstrous disrupt the boundaries of the normal, whether a matter of size, shape or morality.

Elaborating on the relationship between the monstrous and the enormous, Canguilhem (1962: 28) argues that 'both are well beyond the norm', but that the enormous merely escapes the norm in a metric sense. What makes the enormous monstrous, however, is that 'after a certain degree of growth quality becomes questionable.' Hypothetically assuming that 'man is defined by a certain limitation of forces and functions', Canguilhem adds that 'the man whose largeness carries him beyond the limitations of man is no longer a man.' The enormous, then, is monstrous to the extent that it disrupts the normal boundaries of human size and magnitude.

The words monster, monstrosity and monstrous all emerge from Latin monstrum, which means portent, omen or sign, and from monere, which means to warn. Moreover, they are related to monstrare, which means to show, demonstrate or prove (see Munro 2001). In Medieval and Renaissance theology and medicine, monsters were signs of God's wrath against human sin. Whereas a monster embodying unusual 
and irregular features was seen as an illustration and punishment of past sins, prodigies, i.e. monsters found so horrible and fearsome that they would terrify humans, even announced greater punishment to come and not seldom the end of the world. Monsters such as hermaphrodites were outside the course of nature; prodigies such as a child born with a dog's tail were completely against nature, results of abhorrent acts of bestiality (Davidson 1991; Daston and Park 1998). Both were outside or contrary to nature because of their heterogeneity, which disrupted the boundaries between beings that should be kept apart. Further, the sixteenth century physician Ambroise Paré - often regarded as the father of modern surgery reaffirmed Hippocrates' argument that monsters could be the material products of maternal imagination (Canguilhem 1962; Davidson 1991). Monsters did not merely exist in the imagination, but resulted from images entertained by the woman at the time of copulation or during pregnancy. For example, just thinking of or seeing a pig during pregnancy could produce an offspring with the cloven hooves of a pig. An appeal to maternal imagination could undermine accusations of bestiality, but it also facilitated the idea central to later malestream science, that women are fundamentally irrational and require strict discipline. Despite the unease and horror monsters provoked during the Middle Ages and the Renaissance, they were not separated from the rest of the world (Canguilhem 1962) - monsters lived next to normal beings.

Historically, the understanding and treatment of the monstrous is far from unequivocal. Denouncing the imagination as 'the mistress of all error' (Canguilhem 1962: 32), Pascal paved the ground for a modernist science of monsters in the Classical Age. As the imagination was increasingly dissociated from the scientific demonstration of facts, natural laws and regularities, a de-monstrated understanding of monsters started to emerge in the life sciences. As if their existence could not be 
demonstrated unless they first were de-monstrated, monsters were folded into the regular order of nature and the organization of life. Whereas the Middle Ages and the Renaissance located monstrous phenomena outside nature yet allowed them in the same social world as everybody else, the eighteenth and nineteenth centuries through hospitals and asylums - increasingly separated monsters from the rest of society whilst regarding them as an ingrained part of the natural order. Removing God and the imagination from the causal explanation of monsters yet maintaining nature's dependence on God, monsters were considered a necessary element in the origin of life.

\section{The organization of monsters}

Canguilhem and Foucault draw attention to the focus on monstrosities within French life science in the eighteenth and nineteenth centuries, a period that Hoskin (1995) drawing on Foucault (1970) - has called the age of organization. Foucault (1970) explains how Maupertuis, in opposition to preformism, spoke of a "system of errors to infinity" where living beings - with succeeding generations - spontaneously change to finally become unrecognizable from their originally given character. ${ }^{6}$ In the words of Canguilhem (1994: 209), Maupertuis saw structural variation as 'the rule of organic progression'. This emphasis on spontaneous change and structural variation in the origin of life was closely related to the existence of monsters, as 'The visible species that now present themselves for our analysis have been separated out from the ceaseless background of monstrosities that appear, glimmer, sink into the abyss, and occasionally survive' (Foucault 1970: 154; my italics). Furthermore, Maupertuis shared Leibniz' position that whilst monstrosities constitute a necessary transitional stage in the natural development of species, they themselves could give rise to new 
species and their repetition 'could have given rise to the infinite diversity of animals that we see today' (quoted in Canguilhem 1994: 210). ${ }^{7}$

In a similar vein, Robinet argued that between the extremes of the most basic organic form of the mineral and the most complex form of the human 'lie all the possible degrees of complexity and combination - like an immense series of experiments, of which some have persisted in the form of continuing species and some have sunk into oblivion.' But even though monsters in most cases have sunk into oblivion, Robinet stressed that they "are not of a different "nature" from the species themselves' (Foucault 1970: 155). Rather,

We should believe that the most apparently bizarre forms [...] belong necessarily to the universal plan of being; that they are metamorphoses of the new prototype just as natural as the others, even though they present us with different phenomena; that they serve as means of passing to adjacent forms; that they prepare and bring about the combinations that follow them, just as they themselves were brought about by those that preceded them; that far from disturbing the order of things, they contribute to it. It is only, perhaps, by dint of producing monstrous beings that nature succeeds in producing beings of greater regularity and with more symmetrical structure (Robinet quoted in Foucault 1970: 155; Foucault's omission; my italics).

In conclusion, as guarantors of difference and continuity, monsters were seen as a necessary component in the order of things that enabled life to succeed and new species to emerge. ${ }^{8}$ 
The idea that monsters may result in distinct species persisted into the nineteenth century, particularly in the zoology of Étienne Geoffroy Saint-Hilaire and his son Isidore. Assuming that species transformation (e.g. from reptile to bird) is due to accidental change in the environment and developmental change in embryogenesis, Geoffroy the elder argued that a group of living beings is monstrous until it arises as a new species. And whereas monsters arise from non-adaptive change, "hopeful" monsters transform into new species when undergoing adaptive change (Asma 1996). To Geoffroy the elder, being monstrous was therefore about being in-between species boundaries. And being a "hopeful" monster implied transcending - or de-monstrating - one's monstrosity.

Continuing to emphasize the role of monsters in the organization of life, Geoffroy the younger, who was an authority on deviation from normal structure, viewed monsters as the most serious form of anomaly. In his view, 'Monstrosities are very complex anomalies, very serious, making the performance of one or more functions impossible or difficult, or producing in the individuals so affected a defect in structure very different from that ordinarily found in their species [...]' (Canguilhem 1989: 134; emphasis omitted). But as his understanding of monsters as anomalous was etymologically inaccurate, he insisted that monsters have nothing to do with disorder and irregularity. ${ }^{9}$ Rather, to be anomalous - and hence to be monstrous - was to be morphologically unusual and unaccustomed, 'to be removed, in terms of one's organization, from the vast majority of beings to which one must be compared' (Canguilhem 1989: 133). Hence, there was order and regularity among all anomalies, including monsters. 
Given the significant role attributed to monsters in the origin of species, these monsters should not be conflated with hybrids. Whereas hybrids (such as the mule) which are the results of interbreeding - were (and still are) generally regarded as sterile, monsters were unusual or irregular offspring of same species individuals who did not look like their parents. Although their survivability within and across generations was questioned, their reproductive ability per se was not necessarily seen to be affected by their monstrosity. It was therefore the repetition and reproduction of monstrous features that eventually could give rise to new species. However, by the first half of the nineteenth century scientific interest in monsters had become largely instrumental. Increasingly subjected to the methods of Enlightenment rationalism, monsters were collected, experimented upon, classified and analyzed in comparison to normal organisms. Though significant, monsters remained marginal in this discursive formation whose debates revolved around concepts and phenomena of organization. Primarily 'useful as a foil for the norm' (Canguilhem 1962: 35), they were folded into the organization of life. Thus, the life sciences at the time may be viewed as an organization theory preoccupied with the organization of life, bodies and nature, an organization very much incorporating monsters.

Writings in the history of science do not give a clear-cut answer as to why, towards the end of the nineteenth century, the instrumental utilization of monsters was followed by a much stronger emphasis on normal organisms and effectively a neglect of monsters. In other words, it is not straightforward why the existence of monsters came to throw doubt on life's ability to teach us order; how monsters became beings of negative value; and how the normal type came to signify the zero degree of monstrosity (Canguilhem 1962: 27; 28; 29). From Canguilhem's (1962) rather convoluted argument it is possible to tease out that this has much to do with 
difficulties (i) finding large samples of monsters, (ii) studying monsters over long time spans and across generations, and (iii) deriving universal laws from the study of monsters. Darwin's growing impact is not contrary to this. Although Darwin was influenced by nineteenth century teratology (Asma 1996), he became more concerned with the qualities of new species than with the deviant features of intermediary monstrous life forms. ${ }^{10}$ It is worth noting that it is a post-Darwinian biology void of monsters that was adopted by the pioneers of organization theory (e.g. Mayo 1933, Barnard 1938) and their population ecologist followers (e.g. Hannan and Freeman 1977).

The impaired status of monsters was earlier noticeable within other parts of Western high culture. With the Enlightenment the socio-cultural elites came to regard the collection and display of monsters as vulgar, amateurish and childish (Daston and Park 1998). ${ }^{11}$ And by the turn of the nineteenth century monstrous bodies were increasingly subjected to fierce repression and attempts at elimination by joint efforts of science and governments. The eugenic methods of coercive sterilization, selective breeding and enforced adoption and incarceration targeted to organize populations were far from specific to Nazi Rassenhygiene, but were pursued by most Western governments between 1900 and the 1960s. ${ }^{12}$ Freud's (1955) essay on the uncanny (das Unheimliche), which according to Samuel Weber (1999) has remained marginal in the field of psychoanalysis, may be related to this trend, as it offers rich insights into the monstrosities of the unconscious. In short, the uncanny concerns the anxieties that, reminding us of death and danger as well as of our own bodily and mental vulnerability, impurity and incompleteness, haunt us, not so much as external threats, but, as Shildrick (2002) argues, by the threat of their return. The uncanny is therefore 'something familiar that has been repressed' because it causes anxiety (Freud 1955: 
247). Part of the uncanny are even sexual and bodily desires of which we often remain unconscious and which disrupt the rationalistic strives of the ego and the moralistic efforts of the super-ego to lead an economic, civilized and well-mannered life. While Freud was pessimistic about humanity's ability to tackle the monstrosities of the unconscious, he argued that some of the problems involved can be handled, organized and expelled from the psyche through psychoanalysis. Not unlike the Cartesian organization of the animalistic, irrational body by the human, rational mind, Freud's understanding of the uncanny suggests that monstrous, boundary-disrupting aspects of embodiment provoke anxieties and monstrosities in the psyche that in turn are in need of psychological organization.

Not completely excluded, but further marginalized from society's elite institutions, the monstrous was with few exceptions relegated to a popular culture of freak shows and travelling circuses. In the following section I shall discuss examples from freak show culture as well as the two performance artists Orlan and Bob Flanagan. Emphasis is put on the ways in which these monstrous bodies may disrupt boundaries that often organize how people perceive and relate to others. The below reference to freaks as monstrous bodies has no pejorative intentions. On the contrary, without uncritically celebrating this culture, it seeks to undermine the stigmatization of freaks through a combination of sympathetic engagement and critical distance.

\section{Monstrous bodies in freak shows and performance art}

Whereas the repression of monstrous bodies was intensified during the first half of the twentieth century, attempts to colonize, co-opt and capitalize on the monstrous have a long history in the circuses and freak shows touring the towns and villages of Western 
countries. Like the flourishing interest in monsters in premodern times, the popularity of these events is related to a strong fascination by which monstrous and grotesque bodies are found disturbing and attractive. Typically diverging from predominant images of the perfect human body, freaks are seen to disrupt boundaries between humans and animals.

Fred Wilson from Somerville, Massachusetts, known as "Lobster Boy Fred Wilson", remains one of the most famous modern examples of monstrous bodies (see figure 1). Wilson attracted huge crowds as he toured the US in the late nineteenth century exposing his severely clawed hands and warped feet. But wearing his Sunday best, he is humanized rather than animalized. As Davidson (1991: 64) writes, 'one is drawn as much to his human face as to his lobster claws.'

\section{[Figure 1 here]}

The humanization of freaks, Davidson continues, is central to the modern freak show. By the 1890 s, most circuses consisted of a multiple ring system that drew attention to contrasts of scale (e.g. dwarves and giants) as well as internal contrasts (e.g. bearded ladies and hermaphrodite men). Rather than displaying horrors, these circuses were in the business of entertainment and titillation. As an abhorrent body would tend to fix audience attention, it would hold back audiences from moving between attractions, from one ring to the next. This is not to say that freak shows revolved around the normality of freaks or that working conditions were humane. Rather, these shows may both reinforce and disrupt the boundary between the normal and the abnormal. And to the extent that the latter is the case, they accentuate the constructed nature of these categories that often organize social identity and interaction. 
In his classic film Freaks (1932), the director Tod Browning cast a number of people regarded as having monstrous bodies. However, Browning's movie was not simply an attempt to make money on or contribute to their further ridicule and stigmatization, but can be seen as a subversive attack on his employers, the huge Hollywood production company and glamour factory Metro Goldwin Mayer (MGM) that was best known for its large-scale cinematic worship of conventional beauty. ${ }^{13}$ Furthermore, Browning sought to make a sympathetic portrayal of the freak cast, portraying famous performers such as the opera-singing conjoined twins Daisy and Violet Hilton (see figure 2) in everyday situations - cooking, knitting, and being courted by their boyfriends. The film also shows "The Bearded Lady" Olga Roderick (see figure 3) giving birth to a normal child, and Randian, known as "The Caterpillar Man" or "The Armless and Legless Wonder", rolling and lighting a cigarette with evident ease and mastery (see figure 4). The portrayal of Randian is particularly interesting. The only black performer in the film, he is also the only one who is filmed while looking straight into the camera. ${ }^{14}$ Whereas his cigarette trick suggests the possession of superhuman skills, this emphasizes his very conscious - and human way of performing. Instead of reinforcing the monstrous nature of its "freakish" cast, seeing them in these situations disrupts the boundaries between the normal and the abnormal, the everyday and the monstrous. And whilst this focus avoids reducing monstrous embodiment to something normalized and homogeneous, this disruption is reinforced by the film's narrative plot not being about the characters' monstrosity per se, but about the normal bodied circus star Cleopatra's (Olga Baclanova) attempt to lure the midget Hans (Harry Earles) from his inheritance.

[Figure 2 here] 
[Figure 3 here]

[Figure 4 here]

Tami Gold's film Juggling Gender (1992), which is a loving portrait of Jennifer Miller - a lesbian performer with a full beard - does in some way continue Browning's tradition. Miller, who often is mistaken for a man, comes from a Jewish family where a number of her female relatives developed severe hair growth during puberty. However, in opposition to her relatives, who have sought various remedies to eliminate excess body hair, she has not given in to family and societal pressures, but has been determined to let her hair grow. The film, which shows Miller in the everyday and during stage performances, explores the fluidity of gender, raises important questions about the construction of sexual and gender identity, and draws attention to the difficulty of defining anyone as either masculine or feminine (see figure 5). Though gender transgression may be less stigmatized than it has been, many people are still disturbed by bodies who fit in neither gender, and as a transvestite I have experienced some of the pains following people's need to organize bodies as either female or male, feminine or masculine.

\section{[Figure 5 here]}

In recent years, the monstrous has spread beyond the world of freak shows and to the elite sphere of contemporary art. The French performance artist Orlan started her career in the 1960s selling kisses on the street and became an instructor at the Ecole Nationale des Beaux-Arts in Dijon in 1984, where she currently is a professor. Since 1990, under the umbrella title the Reincarnation of St. Orlan, she has pursued a ten- 
year project involving several plastic surgeries that not only problematize the role of plastic surgery in contemporary Western society, but, more importantly, question predominant images of beauty. During surgery, she often reads aloud from texts by Lacan, Artaud and Kristeva. In November 1993, undergoing her seventh operation titled Omnipresence, Orlan had two lumps put into her temples to create a hornlike appearance (see figure 6). The operation was transmitted real time by video-link to galleries in New York, Paris and Tokyo.

[Figure 6 here]

In 2000 the project culminated in Tokyo with the construction and fitting of the largest nose her face could support. The same year she experimented with skin colour and hair in the photographic series Self-hybridation africaines. Though risking to trivialize differences of race and ethnicity and the sufferings of black people, these photographs may destabilize predominant stereotypes of racial difference. The theme of bodily difference indicates a significant contrast between Orlan and the freaks of the travelling circus. Whereas performers in freak shows typically have had to exploit an embodiment of disability which it is difficult to escape and which restricts their participation in everyday life, Orlan's operations have not yet implied considerable constraint in this respect.

Inhabiting the borderland between freak show and performance art, the American performance artist Bob Flanagan combines chronic disease and disability with sexuality. Born with cystic fibrosis, a severe respiratory illness that causes excessive, thick mucus to accumulate in the lungs with resulting chronic infections, Flanagan is also a masochist. By inflicting more pain than the disease, masochism became a way 
to deal with his medical condition. Most sufferers of cystic fibrosis are not expected to live beyond twenty years of age. Flanagan died in 1996 at the age of forty-three. In addition to writing and performing poetry and folksongs, doing stand-up comedy and SM workshops, Flanagan has displayed his body live in art galleries, hanging upsidedown from the ceiling with the support of wires and hooks forced into his flesh (suspension), exposing his sewn up genitals, or pinned down to a table by bolts, shackles and cuffs fixed tightly around his arms and legs (bondage) (see Flanagan 2000). In the exhibit 'The Wall of Pain' (1982), dozens of photographs of Flanagan's face taken by his partner and dominatrix Sheree Rose show Flanagan's variety of responses to Sheree's floggings, which range from fear and outcry to laughter and joyous anticipation. Pain and pleasure are juxtaposed to astonishing effect. On the whole, Flanagan's monstrous art disrupts bodily boundaries, not just between pain and pleasure, but between health and illness, the human, subhuman and superhuman. Able to take more pain than most, Flanagan, who called himself a supermasochist, transgressed the boundaries of the human condition as well as the conditions under which humans ostensibly are able to live (see figure 7).

\section{[Figure 7 here]}

Typically attracting a more elite audience than the average freak show, the Gestaltung of monstrosities within performance art may have increased the cultural credibility of the monstrous. Nevertheless, performance art remains at the margins of the art world and the monstrosities constituted by Flanagan remain at the margins of performance art, which often privileges the fit bodies of modern dance. However, monsters are not just peripheral to elite culture, and on a more theoretical level monstrous aspects of 
boundary disruption have been explored in recent social science and organization theory. This is examined below.

\section{Monsters in social science and organization theory}

With the anthology A Sociology of Monsters (Law 1991a), scholars in Actor-Network Theory (ANT) were the first social scientists to explicitly address the problem of monsters. ANT is particularly concerned with the sociotechnical relations between humans and machines, and Law (1991b) suggests that it is the relations between such entities that create monsters. Though the heterogeneity of these entities and their relations is crucial here, their monstrosity also has to do with continuity and with the idea that differences and distributions drawn between them could be otherwise. Monsters are continuous because they are not separate from other entities, and things could be otherwise because power relations and the distribution of resources between heterogeneous entities could be different. Despite claiming that 'we are all monsters', Law (1991b: 18) admits that some monsters are so privileged that they 'scarcely look like monsters at all.' A sociology of monsters should therefore investigate the sources of privileges and, more importantly, the pains of those monsters who are most stigmatized and marginalized.

Star (1991) resumes this theme. Adopting a more narrow yet more elaborate understanding of monsters, she argues that monsters are marginal and outcast, 'the embodiment of that which is exiled from the self' (Star 1991: 54). Hence, this monstrous self, which Star thinks of as cyborg and impure, is very different from the executive self who usually occupies traditional histories of science and technology. It is monstrous in two respects. Firstly, because it brings together the split personalities 
of secretaries, wives, laboratory technicians, etc. that are created to deal with abuse, pain and terror. And secondly, because the people and work implicated in this self are often invisible in accounts of human encounters with technology. In order to gain access to these heterogeneous selves and improve the multivocality of studies of science, technology and society (STS), Star (1991: 29) proposes to refuse 'those images of the executive [...] which screen out the work that is delegated' to secretaries, wives, laboratory technicians, etc. And, claiming that as members of more than one community of practice we are all marginal in some regard, she stresses the importance of recognizing how multiple membership not only is a marginality, but even a power that resists violence. The challenge is to deal with memberships that are more marginal and monstrous than others since they frequently provoke repression from core entities whilst resisting and disrupting the power of core entities. Richards (1996) makes a similar point in her critique of mainstream sociology of scientific knowledge (SSK) and its insistence on methodological and political neutrality. Sceptical of Haraway's (1991, 1992) notion of "situated knowledges", which risks romanticizing the marginal, Richards argues for the self-reflexivity of SSK research and proposes to view the researcher as a monster who is marginal to, or simultaneously inhabiting, a number of intersecting social worlds.

Studies of monstrous bodies from an ANT angle adds to the understanding of marginality and resistance. In the text discussed above, Star (1991) examines how the standardized mass production system of McDonalds is incapable of dealing with her allergy to onions, which defies the organizational routines of the fast food assembly line. In a different vein, Moser and Law (1999) draw attention to the difficulties a severely disabled woman faces in everyday encounters with technologies that are illadapted to her body or to each other. For example, while the wheelchair on its own 
allows her much mobility, it creates problems when she wants to travel by train. Not only are these encounters between bodies and technologies monstrous insofar as they involve connections between heterogeneous entities. They are even monstrous insofar as the bodies themselves disrupt the boundaries of the ordinary. On the whole, however, the preoccupation in ANT and STS with cyborg or hybrid connections between humans and technologies, which express a human desire for disembodiment, has resulted in less attention being paid to the monstrous aspects of embodiment as such. Moreover, Latour's (1987) ANT maxim, that all relevant entities and relationships must be included and described, is not unproblematic. For example, in Law's (1987) study of fifteenth century Portuguese maritime expansion, description need not have stopped with the associative labours of galley builders and their assembling of wood, men, pitch and sailcloth. According to ANT methodology, more entities should have been included, but the impact of air, food, the earth and daylight (Button 1993), religious symbols and acts of worship, are all monsters that go unnoticed and unrepresented. According to Bloomfield and Vurdubakis (1999), this means that ANT fails on its own premises.

Turning to the organizational theorizing that deals explicitly with monsters, the relatively sparse writings here are not unrelated to ANT. Munro (2001) invokes the notion of monsters to study problems of multiple membership in relation to the different status of numerical and narrative accounts in a management accounting system. Whereas numerical accounts are held to "pass muster", narrative accounts that often involve personal circumstances are deemed monstrous because they are unable to legitimately make up for gaps in numerical accounts. In contrast to much ANT, which emphasizes the durability of heterogeneous connections - ordinary or monstrous - Munro highlights the motility of the ordinary by illustrating how the most 
ordinary, and most acceptable, of phenomena - such as the excuse of having an ill spouse - can be turned into something monstrous that does not fit organizational procedure, routine and culture and therefore does not "pass muster". What seems ordinary one moment may seem monstrous the next and vice versa.

Bloomfield and Vurdubakis (1999) deal more explicitly with the monsters of organization. Their starting point is the effort by contemporary processual organization theory to analyze organization in terms of labours of association and division. On the one hand, organization involves assembling and stabilizing 'a diffuse system of human and non-human entities' (Bloomfield and Vurdubakis' 1999: 626). On the other, it means 'distinguishing the inside of the organization' from its outside, be it keeping organizational interests from personal interests or technical matters from non-experts. Inspired by Cooper $(1986,1997)$, they theorize this relationship in terms of placement and displacement. Organization implies 'finding a place for everything and keeping everything in its place' through imposing limits and maintaining boundaries. Disorganization is the 'loss of place or displacement' (Bloomfield and Vurdubakis 1999: 626). ${ }^{15}$ Unusual in organization theory, their focus is how this displaced outside - populated by monsters - is articulated in various discourses, including science fiction, natural science and news broadcasting. Bloomfield and Vurdubakis suggest a tripartite classification of representations of monstrosity, all of which provide different ways of dealing with failures of organization: (i) monstrosity as distorted mirror; (ii) monstrosity as subversion; and (iii) monstrosity as undecidability. Monstrosity as distorted mirror, which abounds in science fiction, typically offers an anthropomorphic view of monsters, as "aliens with pointed ears". The paradox of displacement is dissolved into a series of quantitative differences which remind of managerialist attempts to manage diversity, where the otherness of 
monsters can be adapted and utilized through for example the Japanization of Western business. Monstrosity as subversion problematizes anthropomorphism, often along postmodern lines. Running the risk of monster celebration, this approach views monstrosity as 'a crack in the supposedly natural order of things' that can overturn the dominant social order (Bloomfield and Vurdubakis 1999: 639). Monstrosity as undecidability offers no ultimate resolution to the displacement produced by monsters since it is difficult to identify one explanation to it. Monsters are part of life, even organizational life, and they can neither be utilized to fix organizational problems nor - in a goal-directed manner - overturn particular organizational regimes. Finally, Bloomfield and Vurdubakis (1999: 641) claim that the current encroachment of work on leisure and the erosion of the office/home boundary is one occasion of monstrosity, displacement and disorganization since such (re)organization 'can be portrayed as causing the de-differentiation of the elements it brings together.' But without discussing the resistance inhabiting domestic life and work, this may be reduced to a play on words, as the same situation implies an expansion of organizational boundaries and a colonization of domestic life.

Though the two previous accounts highlight monstrous aspects of organizational life, it may be worthwhile to consider Parker's (2000) discussion of cyborg couplings between bodies and technology in science fiction and Dale's (2001) examination of the anatomizing urge in organization theory, both of which provide a more corporeal focus. Briefly describing two main kinds of monsters - those of organizations and those outside organizations - Parker argues that in the latter (exemplified by the Alien trilogy) the monster is from the outset an enemy of the organization that even may feed on the organization's attempt to extinguish it. In the former, a monster may be an organization or an organizational creation carrying out the evil goals of an 
organization, which - in cases where the organization loses control - turns back on it or takes the assignment so far that it may threaten the existence of the entire world. However, the key word here is cyborg, not monster, and Parker does not investigate monstrous couplings beyond bodies and technology. ${ }^{16}$ Invoking Kristeva's (1982) concept of abjection, Dale shows how the establishment of organization theory as a distinct academic discipline with a homogeneous self identity is related to the construction of the human body as a structured and organized entity. Like the privileging of the normal, homogeneous and bounded organism in biology, organization theory excludes foreign, abject and monstrous bodies and elements through the initiation and maintenance of boundaries. For example, this explains organization theory's bias towards processes of production and its relative neglect of reproduction, as the latter is typically associated with the monstrous relationship between mother and foetus.

The monstrosities of motherhood as well as the notion of monstrous embodiment are explored in much detail by Shildrick (2002), who, inspired by poststructuralist theory and feminist work on the body, seeks to embody the monster. Investigating examples across medicine, theology and science (including conjoined twins, maternal imagination and the monstrosity of motherhood) Shildrick shows how the monster's uncontainability and unknowability offers a way to rethink the relation with normality as uncontainable and unknowable. Since the monstrous other even is inside of us, the self is fundamentally vulnerable. Together, the uncontainability and unknowability of the monster and the vulnerability of the self means that the self is always at risk of being harmed. In turn, this implies a transformation of the self-other relationship that puts the vulnerable self and the monstrous other in a constant condition of becoming. Here, Shildrick provides a critical examination of Levinas, which facilitates 
understanding of the role of vulnerability in the self-other relationship. Indeed, the monstrosity and vulnerability of the embodied self may be utilized to examine the vulnerability and monstrous other of organizational entities and processes. Unfortunately, the implications of the "constant condition of becoming" resulting from this vulnerability is left relatively unexplored. A further weakness concerns Shildrick's appeal to postmodernism and a "monstrous borderland" where all distinctions are undone - the problem being that even monstrous borderlands with disrupted boundaries presume borders. And pointing to deconstructionism's paradoxical exclusion of the body, she reinforces this exclusion by working with the rather disembodied work of Derrida and - via a somewhat simplistic reading of Butler (1993) - rejecting any prediscursive body. ${ }^{17}$ This is ironic, given Shildrick's earlier assumption of the unknowability of monsters.

Deleuze and Guattari's (1988) example of wasp-orchid symbiosis - which also extends to heterogeneous encounters between humans and non-humans - draws attention to the pre-discursive becoming of monstrous embodiment. In order to open up the notion of monstrous embodiment beyond discursive construction and prepare the development of a monstrous organization theory, it is to this example and their concepts of creative involution, transversal communication and machinic assemblage that I turn in the subsequent section.

\section{Monstrous becomings}

Deleuze and Guattari's (1988) notion of creative involution, which springs out of their more general emphasis on becoming, is highly influenced by Bergson's (1944) concept of creative evolution, previously discussed by Deleuze $(1988,1994)$. But 
unlike creative evolution, which stresses the relationship between the human and the undifferentiated whole of the virtual, creative involution draws attention to the monstrous couplings and transversal communications between heterogeneous bodies across the phyletic lineages and organic boundaries of species. Like Darwin (1996), Deleuze and Guattari's favourite example concerns the symbiotic and sympathetic relationship between the wasp and the orchid. But whereas Darwin used it to illustrate the complexity of natural selection, they use it 'in order to show how living matter can evade or transform "selective pressures", (Ansell Pearson 1999: 144). Moreover, as Darwin's evolutionism on the whole focuses on filiative relations within distinct species, cross-species fertilization is not central to it. It is crucial, however, to Deleuze and Guattari's project, which involves 'a different order than filiation' constituted by 'alliances which cut across phyletic lineages' and allow for "'the dance between the most disparate things", (Ansell Pearson 1999: 162; 68).

According to habit, common sense and mainstream science, the wasp and the orchid not only constitute two different species. There are between fifteen thousand and thirty-five thousand species of orchids and more than one thousand species of wasps. Typically, they are also seen to belong to two different kingdoms - the former to the insect phylum within the animal kingdom and the latter to the plant kingdom. In this respect, their special relationship may seem no less than a natural wonder. Analyzing it in terms of transversal communication, Deleuze and Guattari accentuate the radical nature of this monstrous alliance:

The orchid deterritorializes by forming an image, a tracing of a wasp; but the wasp reterritorializes on that image. The wasp is nevertheless deterritorialized, becoming a piece in the orchid's reproductive apparatus. But it reterritorializes 
the orchid by transporting its pollen. Wasp and orchid, as heterogeneous elements, form a rhizome (Deleuze and Guattari 1988: 10).

This rather dense statement may be understood as follows. When 'The orchid deterritorializes by forming an image, a tracing of the wasp', it frees itself from the elements with which it is typically associated and, without letting go of itself, becomes something else. And when 'the wasp reterritorializes on that image', it relates differently to the orchid than it would had not the orchid first deterritorialized itself by forming an image of the wasp. In other words, the orchid behaves in such a way that the wasp thinks the orchid is a wasp. Consequently, and without sexual engagement, they become part of each others' reproductive systems. Their relationship is a rhizomic one of transversal communication because it cuts across the boundaries of species and kingdoms, zoological phyla and botanical divisions, and it is symbiotic because they need one another to reproduce. More specifically, the wasp is as dependent on its possibilities to extract nectar from the orchid as the orchid is on its possibilities to contaminate the wasp with its pollen and be contaminated by pollen transported by wasps from one orchid to the next.

Further on, Deleuze and Guattari argue that the wasp-orchid relationship can be seen in terms of a "machinic assemblage". Their reference to the machine must neither be confused with Freudian desiring-machines nor with the Marxist view of the machine, which, a complex version of the tool, simply is an extension of the human. ${ }^{18}$ For Deleuze and Guattari both conceptions are flawed with an anthropocentrism that must be avoided. The machinic assemblage therefore refers to the monstrous and heterogeneous couplings between different forms of life, such as those between an 
orchid and a wasp, a human and her apparel, a masochist and a sadist, a Sauternes winery and the botrytis cinera fungus ("noble rot"):

We think the material or machinic aspect of an assemblage relates not to the production of goods but rather to a precise state of intermingling of bodies in a society, including all the attractions and repulsions, sympathies and antipathies, alterations, amalgations, penetrations, and expansions that affect bodies of all kinds in their relations to one another (Deleuze and Guattari 1988: 90).

Humans are therefore part of machinic assemblages insofar as they combine with other forms of life, whether technical apparatuses, other humans, animals, or the natural environment. But this does not mean that a machinic assemblage resembles the hybrid described elsewhere (e.g. Haraway 1991). Unlike assemblages, 'hybrids simply require a connection of points and do not facilitate a passing between them' (Ansell Pearson 1999: 197). Consequently, a wasp-orchid hybrid still regards the two as separate beings. In contrast, the transversal communication of a machinic assemblage undermines the distinct nature of different forms of life, 'challenges the boundaries of the organism' (Ansell Pearson 1997: 132) and scrambles genealogical and phyletic lineages.

Illustrating how boundaries drawn to separate different bodies are disrupted, the concept of creative involution also highlights that the categories of knowledge which define different bodies according to species, phyla, divisions and kingdoms are not naturally given, but the result of powerful processes of discursive construction. Dale (2001) helps us understand why species are usually viewed as distinct. It is when it is dead that a body can be cut open, fully morphologized, identified in terms of an 
organic structure and assigned to the bounded categories of different species. In entomology, she continues, the entomologist categorizes an insect and literally pins it down by running a pin through it. Dead, it can be fixed, stabilized and disabled from engaging in further transversal communication with members of other species.

As Deleuze and Guattari reject the purity of species, they view the development of bodies in terms of becoming rather than being. With respect to the wasp and the orchid, their heterogeneous interaction does not mean that the wasp, for instance, as if perfectly differentiated from its environment, evolves from a rudimentary to a more mature stage of what it means to be a wasp. Rather, the wasp is becoming-orchid. Similarly, the orchid is becoming-wasp. Hence, the boundaries between them are not stable, complete and always maintained, but leaky, permeable and unstable. This is central to the notions of creativity and involution. As the orchid deterritorializes by forming an image of a wasp, it creatively influences the wasp to reterritorialize on that image. The wasp is therefore becoming-orchid because the orchid affects something beyond itself - and vice versa. Involution should not be interpreted in Freudian terms, where it would be reduced to a matter of regression. Instead, it should be understood in the mathematical sense where something is folded, caught up, involved and rolled into its introvert. Whereas regression implies moving 'in the direction of something less differentiated' (Deleuze and Guattari 1988: 238-239) (this is also the case in Darwinian evolution), creative involution concerns something that cuts across organic and phyletic boundaries in ways that make it more differentiated and open-ended. Since different forms of life creatively influence one another, they are engaged in open-ended processes of becoming, which means that there will be no end to the wasp's process of becoming-orchid, or indeed any body's becoming-other. ${ }^{19}$ 
Criticisms raised against these and related parts of Deleuze and Guattari's work claim that they risk dissolving all boundaries (e.g. Caygill 1997; Williams 1998; Hansen 2000; Shildrick 2002). Examining the limits of Deleuze' biophilosophy, Caygill (1997) argues that his move to Spinozism (which partly inspired Deleuze and Guattari's study of transversal communication) makes him favour the distribution of relations and capacities in the plane of immanence over Darwinian selection. At the same time, Caygill insists that Deleuze' ethology is unthinkable without selection. However, this is not a Darwinian selection of normal forms, but a Nietzschean selection of the eternal return of extreme forms and a Spinozian selection of joyful, boundary-breaking encounters. Contrary to Darwinism (but in accordance with Geoffroy the elder), ${ }^{20}$ these presume that difference and distribution precede selection - indeed, how can anything be selected unless there is a distribution of differences to select from $?^{21}$ Caygill concludes that this makes Deleuze humanize and sentimentalize selection, moralize nature, and brutalize ethics and politics. But this ignores that Darwinism is open to similar attacks, as Darwinian selection also makes exceptions - based on fitness rather than joy. And, as the open-ended selection of extreme, monstrous life disrupts the boundaries governing the Darwinian organization of life, it includes those bodies that would be exterminated by Darwinian selection and opens up the range of differences beyond those preferred by humanist morality.

Seeking to synthesize creative involution with Maturana and Varela's (1980) notion of organismic autonomy, Hansen (2000: 8) argues that Deleuze and Guattari's 'tendency to privilege the flexibility of the plane of immanence over any constraint imposed by organization [...] risks indulging a familiar posthuman fantasy: to wit, the fantasy that the body can be programmed, that embodied life is simply the consequence of an operation of coding.' But Hansen's reference to a coding and 
programming of the body implies a teleological sense of flexibility contrary to Deleuze and Guattari's emphasis on experimentation and indeterminacy. Further, in their discussion of the body without organs, which often is misinterpreted as a complete disregard of the organism (see Williams 1998; Shildrick 2002), Deleuze and Guattari (1988) insist on its necessary coexistence with the organism. Rather than dismantling the organism completely, experimenting with what a body can do by creating a body without organs requires caution. Similarly, transversal communication and creative involution do not dissolve all boundaries, differences and constraints, but shows how boundaries are creatively subverted. Moreover, Deleuze and Guattari pay much attention to processes of stratification and organization that keep things in their place, and the shift towards themes of disruption, difference and immanence is necessary in order to undermine the exaggerated stress on the power and stability of stratification and organization in mainstream metaphysics, biology and social thought. In the next and final section of this paper, I shall bring forward the monstrous becomings suggested here into the study of monstrous embodiment within a monstrous organization theory.

\section{Towards a monstrous organization theory}

In his critique of functionalist organization theory, Cooper (1986) launches the idea that boundaries not only distinguish between organizational insides and outsides in a process that presumes the extinction of foreign elements from the former. Boundaries are also bonds that bring together different elements from different worlds. In other words, boundaries not only separate different spaces, but constitute marginal yet liveable borderlands and meeting places. These spaces, which often are peripheral, imply a living on the edge combining different heterogeneous forces such as those in 
the monstrous embodiments analyzed above. For example, Randian's disability made him more able than most. Orlan's make-up and plastic surgery does - by conventional standards - make her bodily appearance disturbing rather than attractive. Jennifer Miller has got a fuller beard than most men. And Bob Flanagan was so weak that he could not breathe properly without assistance, yet so strong that he could hammer nails through his scrotum and pin it down to a wooden plank. Indeed, as both Deleuze and Guattari (1988) and some ANT argue, everybody is monstrous to some extent, everybody lives on the edge, whether in terms of a machinic assemblage between a human and the bacteria inhabiting her colon or the multiple memberships occupied by a manager who is also a mother, a colleague, a customer, a lesbian and a political activist.

Whereas a focus on the hybrid aspects of these examples would risk stabilizing the heterogeneous relationships in which they are involved, an emphasis on their monstrous becomings brings out their openness. What would come out of Flanagan's and Randian's tension between disability and ability was unpredictable. Orlan's reconstitution of beauty at the margins of femininity and humanity creates more, not less bodily difference. And Miller's ambiguous gender opens up what it means to be a woman. Together, they disrupt established categorizations of science and society that often organize how people relate to one another. Whereas organization and its assembling of clean-cut, legitimate bodies and elements requires dividing the same from the different, the familiar from the foreign, these monstrous embodiments contradict, undermine and exceed the boundaries of that enterprise. Insofar as organizational efforts of assembling, dividing and boundary-drawing are necessary preconditions for the establishment and maintenance of formal organizational entities (e.g. Cooper and Burrell 1988; Chia 1998), and insofar as monstrous bodies inhabit 
and work in formal organizations, they open up the boundaries of such entities and undermine their persistence. For example, a disabled employee may challenge a corporate culture based on conform impression management. And, as frustrating I know it can be, cross-dressing customers may disrupt the boundaries drawn by manufacturers and retailers of shoes and clothing between demographically defined market segments.

Allegedly, there is a danger that speaking of already stigmatized people as monstrous bodies may lead to further stigmatization and marginalization. However, taking much inspiration from the filmmakers Browning and Gold, I believe it is possible to talk about monstrous embodiment in sympathetic rather than pejorative ways. Moreover, by rethinking ordinary understandings of monstrous embodiment and expanding the monstrous beyond traditional connotations, everybody is rendered monstrous. Although this obviously inflates the term, the problem facing Belleforest five centuries ago is less serious than the current danger of ignoring the monstrous or reserving it for the already stigmatized.

Hence, this is also no attempt to colonize, exploit and capitalize on monstrous bodies. As such, it is contrary to mainstream management and organization theory, which focuses on organizations seeking to control their outside and inside others, whether customers, workers, local communities or natural environments (e.g. Grant et al. 1994; Porter 1998). And it is at odds with the ways in which mainstream scholars seek to protect the discipline from inside others by keeping controversial research out of established journals, major conferences and prominent university departments indeed, the occasional inclusion of controversial work may be little more than a safety mechanism to legitimate current hegemony. As a diverse, academic field, organization 
theory needs monstrous others. Not in order to - by negation - define itself, but in order to understand and give voice to the monstrous embodiments that interrupt attempts to organize bodies according to strict categories and behavioural patterns. And, not in order to achieve "better" organization, but in order to appreciate how processes and entities of organization work, wither and break down. This requires organization theorists to cross the disciplinary boundaries of organization theory and social science and engage with work in philosophy, the history of science and the humanities, which already has a tradition for studying monstrous bodies.

The study of monstrous embodiment within organization theory draws attention to the difference between an organization theory of monsters and a monstrous organization theory. This reiterates Williams and Bendelow's (1998) distinction between the sociology of the body and an embodied sociology. In their view, much research in the sociology of the body is just as disembodied as research in other sociological subfields (e.g. the sociology of organizations, the sociology of education and the sociology of family), the only difference being that it is marginalized compared to its well-established counterparts. The sociology of the body therefore risks turning the body into an area of interest to only a small group of specialists at the periphery of sociology. In contrast, and inspired by feminist research, Williams and Bendelow argue for an embodied sociology where scholars would write their bodily experiences into their research - irrespective of sub-field. Although this may most realistically be embarked upon by researchers already concerned with issues of embodiment, any field of social research may benefit from such contextualization, by which the neutrality and universality of knowledge is radically questioned. The sociology of monsters proposed by Law (1991b) and the organization theory of monsters initiated by Bloomfield and Vurdubakis (1999) and Munro (2001) face problems similar to the 
sociology of the body. Star's (1991) methodological proposal, on the contrary, that researchers should reflect upon their multiple memberships in different social worlds, takes some steps towards a monstrous sociology. However, some monsters are more monstrous than others, and a monstrous organization theory would preferably encourage researchers to reflect upon stigmatized or marginalized aspects of their own embodiment, whether issues of illness, class, age, ethnicity, gender or sexuality. Although this risks marginalizing the study of monstrous embodiment further, this is not just to disadvantage. Peripheral borderlands are often cold, dark and lonely places far away from the enlightened core, but they can also be fertile terrains of creativity where one can experiment with embodiment and thought.

Referring to the teratology - or organization theory of monsters - pursued by life scientists in the eighteenth and nineteenth centuries, Canguilhem (1962) distinguishes between monstrosities and the monstrous. Folding monstrosities into the organization of life, neither the monstrosities of this teratology nor the teratology itself are monstrous. Monstrous embodiments, on the contrary, are excess vital forces greater than the bodies that the organization of life can permit. Although the bodies in question may look the same, what they are seen to be capable of doing differs depending on whether one is working from an organization theory of monsters or a monstrous organization theory. In the former, monsters enable the organization of life. In the latter, they invade, disrupt and exceed the organization of life, creating more bodily difference than organizational processes and entities would like to contain. As a consequence of the monsters invading it, the future of monstrous organization theory - and organization itself - is an open-ended matter of becoming. To paraphrase Derrida (1995), the future of organization theory is monstrous. 


\section{Notes}

1. I wish to thank Gibson Burrell, who first inspired my research into the monstrous, as well as the two anonymous reviewers for their helpful comments. The financial support from the Swedish Research Council and a travel grant from STINT are gratefully acknowledged, as is the hospitality of the Department of Management, Lundquist College of Business, University of Oregon.

2. Francois de Belleforest (1530-1583) was a much noted writer in his time, and he also wrote a version of Hamlet that amongst literary historians is widely held to have influenced Shakespeare's Hamlet.

3. Specifying the term "monster", the literature search combined the Science Citation Index Expanded, the Social Science Citation Index, and the Arts and Humanities Citation Index, all part of the ISI Web of Knowledge.

4. Much of the feminist work in these areas is inspired by Kristeva's (1982) writing on the female body as an abject body.

5. But unlike Bloomfield and Vurdubakis (1999) and Munro (2001), who utilize the notion of monsters to address issues of marginality and heterogeneity, du Gay (1994) simply uses the term as a metaphor to underline the outdatedness, excessive size and inefficiency attributed to bureaucracy in contemporary managerial discourse. Moreover, albeit in brief and without direct reference to monsters, the difference between bureaucracy and enterprise has prior to du Gay's piece been discussed in a similar way by Law (1991c: 182) in A Sociology of Monsters.

6. Pierre Louis Moreau de Maupertuis (1698-1759) was primarily concerned with mathematics and astronomy, but according to the Harvard historian of science 
Ernst Mayr (1982: 328), 'he [also] had a keen interest in biology' and may be counted amongst the pioneers of genetics. Further on, Mayr insists that Maupertuis 'was neither an evolutionist nor one of the founders of natural selection.' Rather, he developed a theory of the origins of life. Critiquing the Newtonian paradigm of forces and motion as too deterministic, creationistic and therefore 'insufficient for biology', he drew heavily upon the notions of spontaneous generation in the works of Lucretius and the Epicurians as well as the continuist notion of the scala naturae ("the great chain of being") in the work of Leibniz.

7. Indeed, to Leibniz 'monsters exemplified the pleasure nature took in variety' (Daston and Park 1998: 201).

8. Strictly speaking, following Mayr (1982: 327), a notion of "new" species is somewhat problematic with respect to the naturalist Jean-Baptiste Robinet's (1735-1820) work as his principle of plenitude implied that 'nothing new was created $[\ldots]$ since the potential for everything was pre-existing'. Thus, "new" species were seen to originate from 'a combination of earlier prototypes.'

9. Canguilhem (1989: 131) explains that contrary to the beliefs of Geoffroy the younger, anomaly emerges etymologically not from the Greek a-nomos ("not law”), but from the Greek an-omalos. As omalos means even, smooth or level, anomalos means uneven, rough and indeed irregular.

10. Of course, the second half of the nineteenth century also experiences the emergence of pathology as the scientific study of disease. However, as Canguilhem (1989: 138-139) points out, disease is not the same as anomaly. Whereas disease is a temporal interruption in the healthy state of the human being, 
anomaly - as in the case of monsters - is "spatial multiplicity", i.e. a divergence from the norm that is constitutional and congenital of the anomalous or monstrous individual. Even in cases where disease becomes chronic, there is always in the individual sufferer a past state of healthiness to which the sick state can be compared. As the anomalous monster has never been healthy or normal it is beyond comparison even to itself. Consequently, it is not only beyond the therapeutic function of pathology. Given their incommensurability, monsters are even beyond the scientific function of modern biology.

11. Indeed, Daston and Park (1998: 19) argue that the diminishing interest in monsters in Enlightenment high culture 'has less to do with some triumph of rationality [...] than with a profound mutation in the self-definition of intellectuals.'

12. Internationally, the US was at the cutting edge of eugenics. Between 1907 and 1940, ‘18,552 mentally ill persons were sterilized in US State hospitals. Some States, beginning with Connecticut in 1896, passed legislation that restricted marriage between nervous and mentally ill individuals. Federal legislation was also passed in the 1920 s which limited immigration from eastern and southern Europe' (Dowbiggin 1992: 379).

13. The MGM owner Louis B. Mayer was so embarrassed by the film that he removed the MGM logo from it and did nothing to fight the ban that kept it out of circulation in the UK for thirty years. He was ready to bury it completely when the exploitation producer Dwain Ester made him a lucrative offer to lease the film for twenty-five years. Ester combined cuts from the film with other material in adult versions such as Forbidden Love, The Monster Show and Nature's Mistakes, which he took on tour across the US. Five years after the film reverted back to 
MGM in 1957, Browning's original version was shown to a sympathetic audience at the Cannes Film Festival.

14. I am grateful to Ylva Habel for bringing this to my attention.

15. As they show, this is eloquently illustrated by Douglas (1966) in her discussion of dirt and disorder as matter out of place.

16. This absence is interesting given the strong connotations between monstrosity and motherhood in the Alien films (see Kuhn 1990).

17. Even though we come to understand bodies through the imprints of discourse, Butler (1993) insists on the existence of a bodily materiality beyond discourse. In other words, monstrous bodies are deemed monstrous through discourse, but the sources of such interpellation lies in their bodily materiality. (I am grateful to Louise Wallenberg for clarifying this point.)

18. In his seminal text 'Machine and Organism', Canguilhem (1992), who was Deleuze's former teacher at the Sorbonne, develops a similar argument, that the machine is just as teleologically governed as the organism.

19. Deleuze and Guattari (1988: 238) elaborate on the distinction between creative involution and Darwinian evolution. While spatial constraints do not permit further investigation of this here, I have discussed this elsewhere in conjunction with the Bergsonian concept of creative evolution, which is pursued by a younger Deleuze in Bergsonism (see Thanem 2001, 2004). The same texts also relate the becomings of the wasp and the orchid to Deleuze and Guattari's various notions of becoming-other (becoming-woman, becoming-child and becoming-animal) and examines these in light of later criticisms (e.g. by Grosz 1994). 
20. Bear in mind that to Geoffroy, it is the return of extreme, monstrous forms that make new species possible.

21. Contrary to Caygill (1997), Ansell Pearson (1997: 184) argues that Deleuze (1994) 'too readily assimilates natural selection into the project of thinking difference and repetition at the level of embryology and morphology' whilst claiming that 'selection works in favour of guaranteeing the survival of the most divergent.' Here, Ansell Pearson adds, Deleuze ‘conveniently ignores Nietzsche’s critique of Darwin, where the critical focus is on the reified notion of "fitness".' Either way, Deleuze's understanding of selection is more akin to Nietzsche's notion of the eternal return than to Darwin's notion of natural selection by which unfit bodies and elements are exterminated.

\section{References}

Ansell Pearson, K. (1997) Viroid Life: Perspectives on Nietzsche and the Transhuman Condition. London: Routledge.

Ansell Pearson, K. (1999) Germinal Life: The Difference and Repetition of Deleuze. London: Routledge.

Asma, S.T. (1996) Following Form and Function: A Philosophical Archaeology of Life Science. Evanston IL: Northwestern University Press.

Barnard, C.I. (1938) The Functions of the Executive. Cambridge, Mass.: Harvard University Press.

Bergson, H. (1944/1907) Creative Evolution, trans. A. Mitchell. New York: Random House. 
Bloomfield, B. and Vurdubakis, T. (1999) 'The Outer Limits: Actor Networks and the Writing of Displacement', Organization 6(4): 625-647.

Butler, J. (1993) Bodies that Matter: On the Discursive Limits of "Sex". London: Routledge.

Button, G. (1993) 'The Curious Case of the Vanishing Technology', in G. Button (ed.) Technology in Working Order, pp. 10-27. London: Routledge.

Canguilhem, G. (1962) 'Monstrosity and the Monstrous', Diogenes 40 (Winter): 2742.

Canguilhem, G. (1989/1966) The Normal and the Pathological, trans. C.R. Fawcett and R.S. Cohen. New York: Zone.

Canguilhem, G. (1992) 'Machine and Organism', in J. Crary and S. Kwinter (eds.) Incorporations, pp. 44-70. New York: Zone.

Canguilhem, G. (1994) A Vital Rationalist: Selected Writings from Georges Canguilhem, ed. F. Delaporte, trans. A. Goldhammer. New York: Zone.

Christiansen, P. (2000) 'Godzilla from a Zoological Perspective', Mathematical Geology 32 (2): 231-245.

Cooper, R. (1986) 'Organization/Disorganization', Social Science Information 25(2): 299-335.

Cooper, R. (1997) 'Symmetry: Uncertainty as Displacement', paper presented at the Limburg/Keele conference on 'Uncertainty, Knowledge and Skill', Hasselt, Belgium (November). 
Dale, K. (2001) Anatomising Embodiment and Organisation Theory. Basingstoke: Palgrave.

Darwin, C. (1996/1877) 'The Various Contrivances By Which Orchids Are Fertilized By Insects', 2nd edn. in T.F. Glick and D. Kohn (eds) On Evolution: The Development of the Theory of Natural Selection, pp. 283-290. Indianapolis IN: Hackett.

Daston, L. and Park, K. (1998) Wonders and the Order of Nature, 1150-1750. New York: Zone Books.

Davidson, A.I. (1991) 'The Horror of Monsters', in J.J. Sheehan and M. Sosna (eds) The Boundaries of Humanity: Humans, Animals, Machines, pp. 36-67. Berkeley CA: University of California Press.

Deleuze, G. (1988/1966) Bergsonism, trans. H. Tomlinson and B. Hammerjam. New York: Zone.

Deleuze, G. (1994/1968) Difference and Repetition, trans. P. Patton. London: Athlone.

Deleuze, G. and Guattari, F. (1988/1980) A Thousand Plateaus: Capitalism and Schizophrenia Volume 2, trans. B. Massumi. London: Athlone.

Derrida, J. (1995) Points: Interviews 1974-1994, trans. P. Kamuf, ed. E. Weber. Stanford CA: Stanford University Press.

Douglas, M. (1966) Purity and Danger: An Analysis of the Concepts of Pollution and Taboo. London: Routledge and Kegan Paul. 
Dowbiggin, I. (1992) ““An Exodus of Enthusiasm”: G. Alder Blumer, Eugenics, and US Psychiatry, 1890-1920’ in Medical History 36 (October): 379-402.

Du Gay, P. (1994) 'Colossal Immodesties and Hopeful Monsters: Pluralism and Organizational Conduct', Organization 1(1): 125-148.

Flanagan, B. (2000) Bob Flanagan: Supermasochist, eds A. Juno and V. Vale. New York: Juno Books.

Forbes (1998) 'Monster Cap for Microsoft', 1 June, 161 (11): 15.

Fortune (2002) ‘Enron's Monster Mess', 4 March, 145 (5): 26-27.

Foucault, M. (1970/1966) The Order of Things: An Archaeology of the Human Sciences. London: Routledge.

Foucault, M. (1979/1977) The History of Sexuality Volume I: An Introduction, trans. R. Hurley. London: Allen Lane.

Foucault, M. (1980) Power/Knowledge: Selected Interviews and Other Writings 19721977 by Michel Foucault, ed. C. Gordon and trans. C. Gordon et al. London: Harvester Wheatsheaf.

Freaks, dir. T. Browning (US 1932).

Freud, S. (1955/1919) 'The Uncanny', in The Standard Edition of the Complete Psychological Works of Sigmund Freud, Volume XVII (1917-1919), ed. J. Strachey, pp. 217-256, London: The Hogarth Press.

Goodman, W.T. et al. (2002) 'Giant Dermatofibroma with Monster Cells', American Journal of Dermatopathology 24(1): 36-38. 
Grant, R.M. et al. (1994) 'TQM's Challenge to Management Theory and Practice', Sloan Management Review (Winter): 25-33.

Grosz, E. (1994) Volatile Bodies: Toward a Corporeal Feminism. Bloomington IN: Indiana University Press.

Hannan, J. and Freeman, J. (1977) 'The Population Ecology of Organization', American Journal of Sociology, 82: 929-64.

Haraway, D. (1991) Simians, Cyborgs and Women: The Reinvention of Nature. London: Free Association.

Haraway, D. (1992) 'The Promises of Monsters: A Regenerative Politics for Inappropriated Others', in L. Grossberg et al. (eds.) Cultural Studies, pp. 295-337. London: Routledge.

Hoskin, K. (1995) 'The Viewing Self and the World We View: Beyond the Perspectival Illusion', Organization 2(1): 141-162.

Juggling Gender, dir. T. Gold (US 1992).

Kristeva, J. (1982/1980) Powers of Horror: An Essay on Abjection, trans. L.S. Roudiez. New York: Columbia University Press.

Kuhn, A. (ed.) (1990) Alien Zone: Cultural Theory and Contemporary Science Fiction Cinema. London: Verso.

Latour, B. (1987) Science in Action: How To Follow Scientists and Engineers Through Society. Milton Keynes: Open University Press. 
Law, J. (ed.) (1991a) A Sociology of Monsters: Essays on Power, Technology and Domination. London: Routledge.

Law, J. (1991b) 'Introduction: Monsters, Machines and Sociotechnical Relations', in J. Law (ed.) A Sociology of Monsters: Essays on Power, Technology and Domination, pp. 1-23. London: Routledge.

Law, J. (1991c) 'Power, Discretion and Strategy', in J. Law (ed.) A Sociology of Monsters: Essays on Power, Technology and Domination, pp. 165-191. London: Routledge.

Maturana, H.R. and Varela, F.G. (1980) Autopoiesis and Cognition: The Realization of the Living. Dordrecht: D. Reidel.

Mayo, E. (1933) The Human Problems of an Industrial Civilization. New York: Viking Press.

Mayr, E. (1982) The Growth of Biological Thought: Diversity, Evolution and Inheritance. Cambridge MA: The Belknap Press of Harvard University Press.

Moser, I. and Law, J. (1999) 'Good Passages, Bad Passages', in J. Law and J. Hassard (eds.) Actor Network Theory and After, pp. 196-219. Oxford: Blackwell.

Munro, R. (2001) 'Calling for Accounts: Numbers, Monsters and Membership', Sociological Review 49(4): 473-493.

New Oxford Dictionary of English (Oxford, Clarendon Press, 1998).

Parker, M. (2000) 'Manufacturing Bodies: Flesh, Organization, Cyborgs', in J. Hassard et al. (eds) Body and Organization, pp. 71-86. London: Sage. 
Porter, M.E. (1998) Competitive Strategy: Techniques for Analyzing Industries and Competitors. New York: Simon \& Schuster.

Richards, E. (1996) '(Un)boxing the Monster', Social Studies of Science 26(2): 323356.

Shildrick, M. (2002) Embodying the Monster: Encounters with the Vulnerable Self. London: Sage.

Star, S.L. (1991) 'Power, Technology and the Phenomenology of Conventions: On Being Allergic to Onions', in J. Law (ed.) A Sociology of Monsters: Essays on Power, Technology and Domination, pp. 24-56. London: Routledge.

Thanem, T. (2001) Disrupting Boundaries: Rethinking Organisation and Embodiment. University of Warwick: Doctoral Thesis.

Thanem, T. (2004) 'The Body without Organs: Nonorganizational Desire in Organizational Life', Culture and Organization 10(3): 203-217.

Williams, S.J. (1998) 'Bodily Dys-Order: Desire, Excess and the Transgression of Corporeal Boundaries', Body \& Society 4(2): 59-82.

Williams, S.J. and Bendelow, G. (1998) The Lived Body: Sociological Themes, Embodied Issues. London: Routledge. 
Torkild Thanem received his $\mathrm{PhD}$ from the University of Warwick. Funded by the Swedish Research Council, he now works as a Research Fellow in the School of Business, Stockholm University. His current research is on the organization and nonorganization of bodies in public health and urban space, and he is also guest editor of a special issue of Tamara on Gilles Deleuze \& Organization Theory. Address: School of Business, Stockholm University, SE 10691 Stockholm, Sweden. [email: tt@fek.su.se] 
Figures

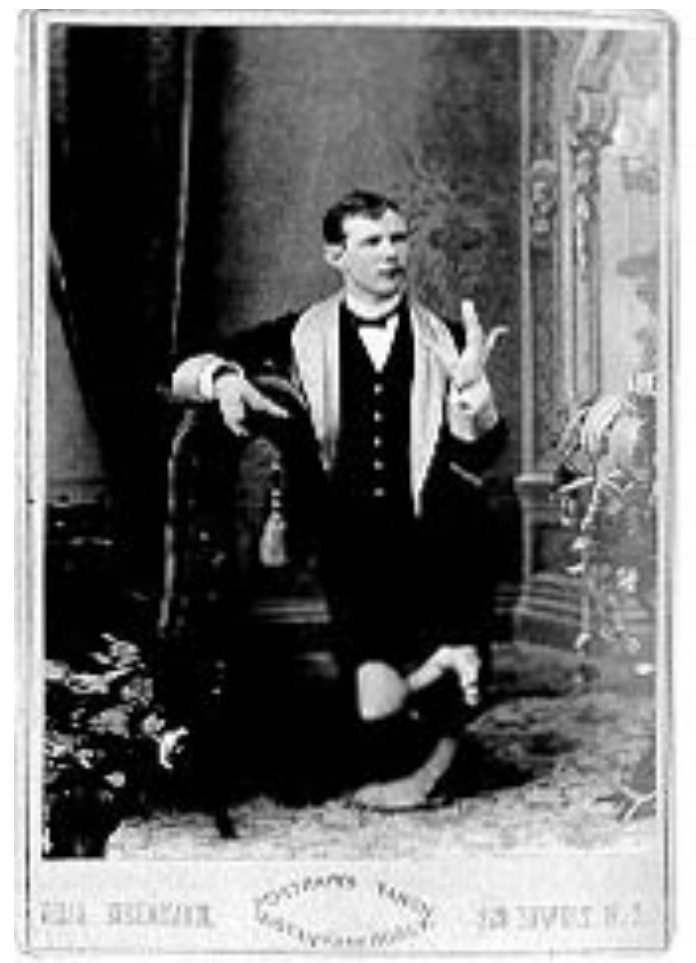

Figure 1: "Lobster Boy Fred Wilson" from Somerville, Massachusetts, as a young man in the 1890s. 


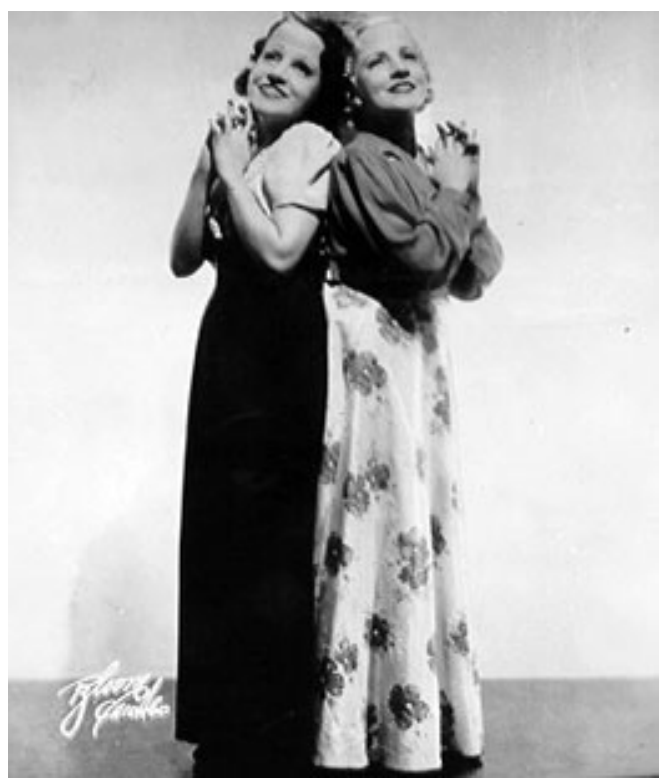

Figure 2: The opera-singing Siamese twins Daisy and Violet Hilton.

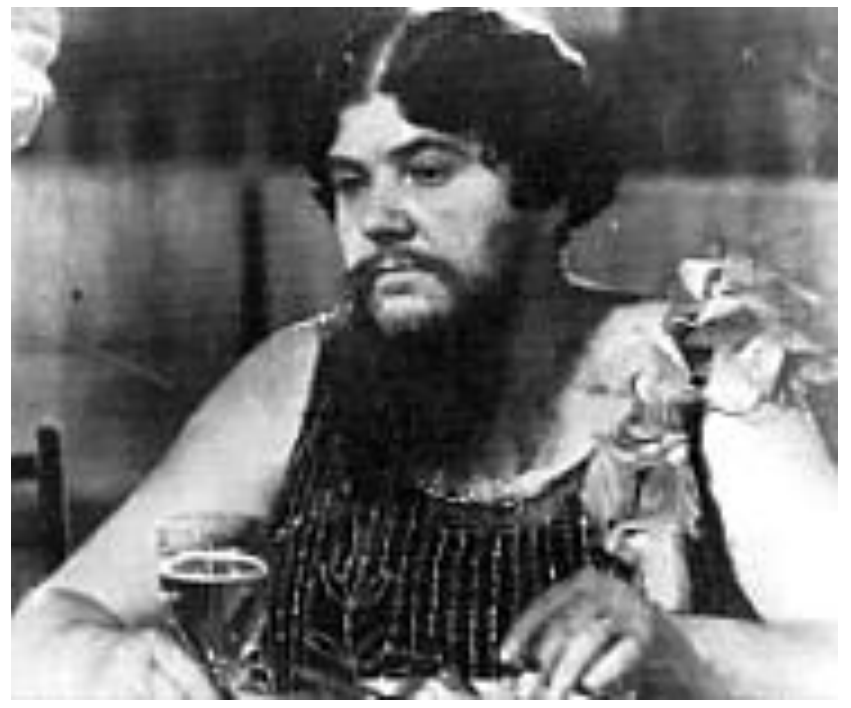

Figure 3: "The Bearded Lady" Olga Roderick. 


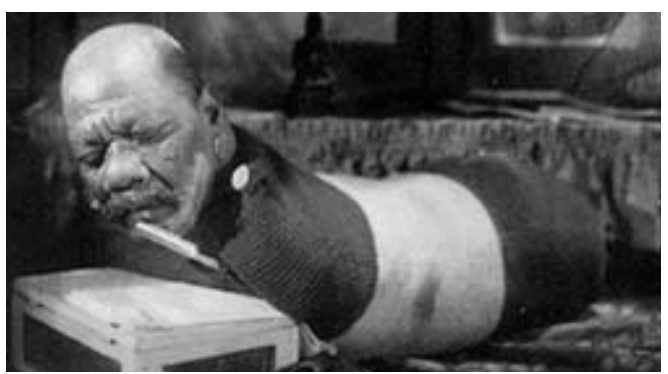

Figure 4: Randian "The Caterpillar Man" and "Armless and Legless Wonder".

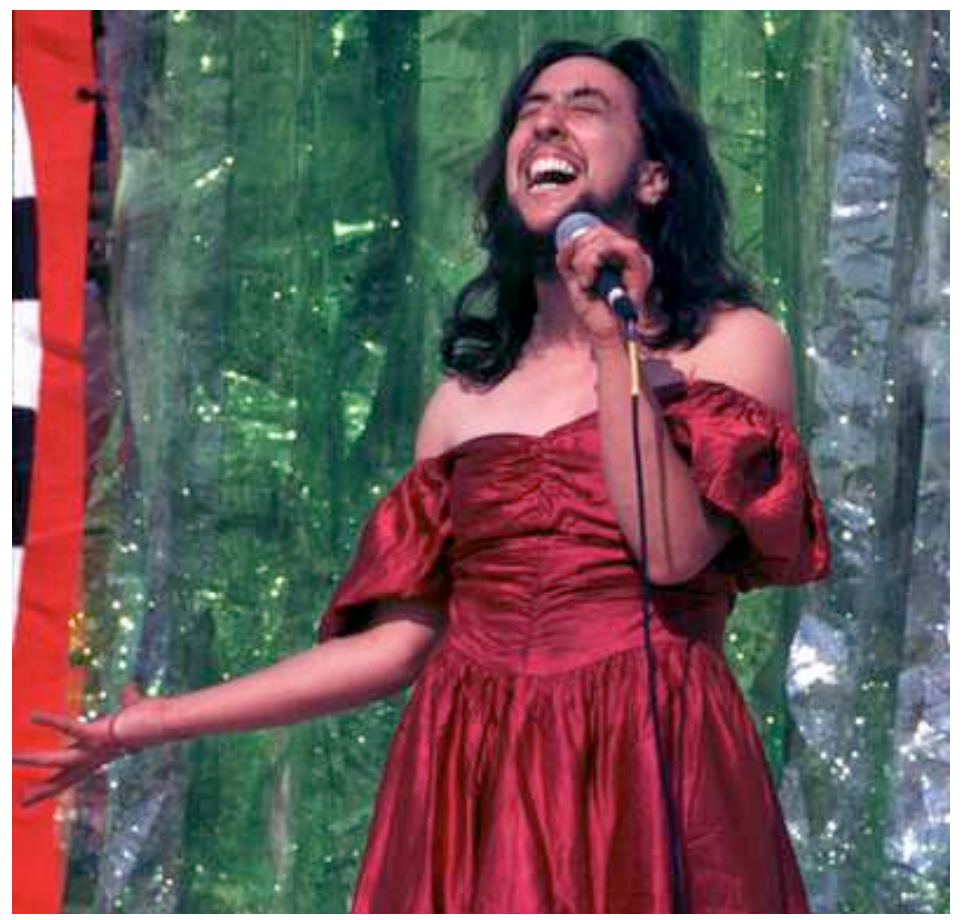

Figure 5: Jennifer Miller performing on stage. Photograph by Andrew Lichtenstein, reproduced with his kind permission. 


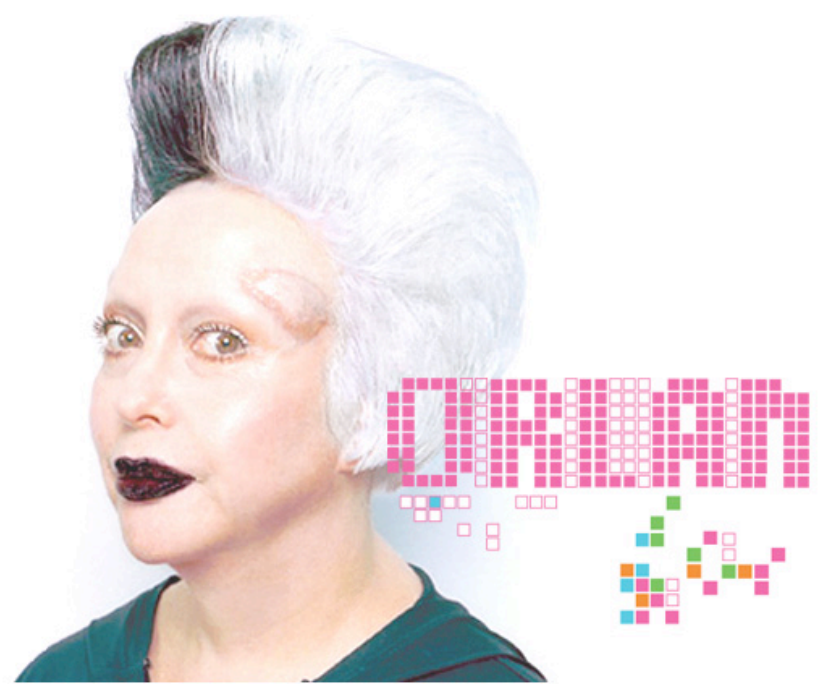

Figure 6: Orlan with hornlike implants some time after the 1993 operation. Photograph by Orlan, reproduced with her kind permission. 


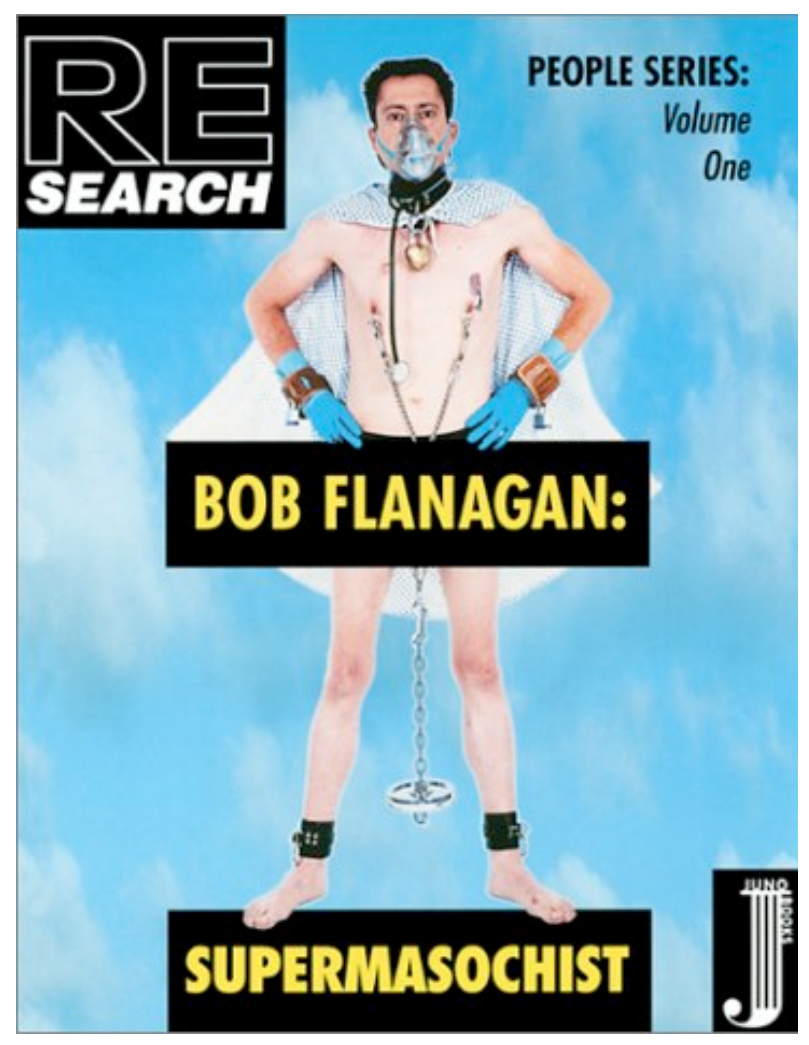

Figure 7: Bob Flanagan Supermasochist on the cover of the book carrying the same title. Photograph by Bob Flanagan and Sheree Rose. 
